The BDJ News section accepts items that include general news, latest research and diary events that interest our readers. Press releases or articles may be edited, and should include a colour photograph if possible. Please direct your correspondence to the News Editor, Richard Ross at the BDJ, 64 Wimpole Street WIG 8YS or by e-mail to bdj@bda-dentistry.org.uk

\section{New GDC Appointments Committee}

The GDC has recruited six people to sit on its new Appointments Committee - an independent group of dental professionals and members of the public who will appoint the members of the GDC's new Fitness to Practise Panel.

The six newly appointed members of the Appointments Committee are:-

Hazel Fraser, Sheila Hewitt, John Hunt OBE, Chris Robinson CBE, Ian Smith and Penelope Vasey MBE.

Appointments Committee members have been appointed for a five-year period. Over the coming months the Appointments Committee, chaired by Sir Graham Hart, will be working to recruit the first members of the Fitness to Practise Panel and develop a training programme for them.

\section{BDA President elect honoured}

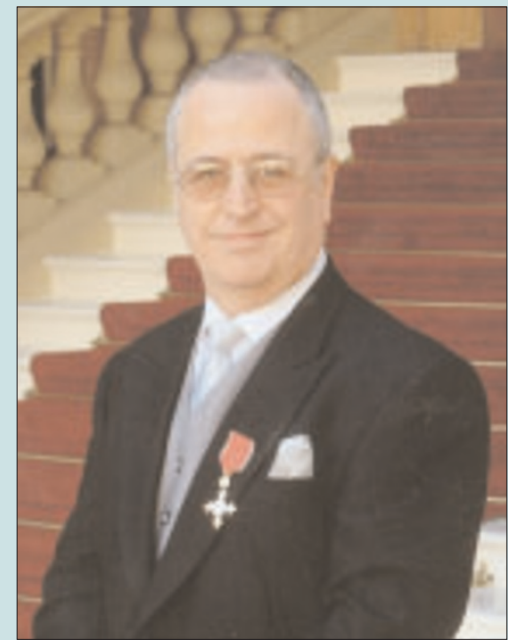

On 20 March 2003, Anthony Kravitz, BDA President elect for the 2004-2005 term, received his $0 B E$ for services to Dentistry from Her Majesty the Queen at Buckingham Palace.

\section{Honorary Fellowship for Professor Gray}

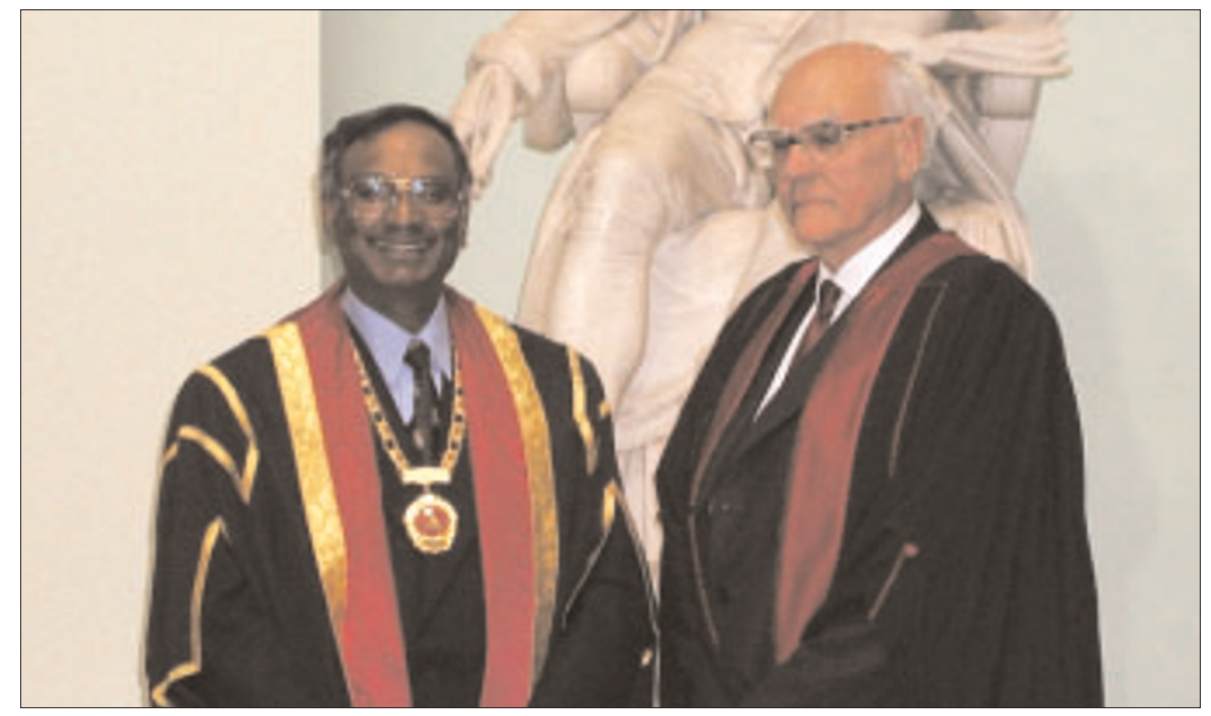

Professor Sir Denis Pereira Gray OBE, right, with Raj RajaRayan OBE, Dean of the Faculty of General Dental Practitioners (UK) at the Presentation of Diplomates Ceremony held on 1 March 2003. Professor Gray's distinguished dental career includes acting as adviser to the World Health Organisation. He is Emeritus Professor at the Institute of General Practice at Exeter University

\section{GDC elects new President}

Hew Mathewson has been elected as President of the new smaller, 29 member GDC. The election took place at the first formal meeting of the newly constituted Council on Thursday 10 April 2003.

Hew Byrne Mathewson is an elected dentist member of the GDC from the constituency of Scotland. He worked as an associate in general dental practice and as a clinical assistant in oral surgery before setting up his own practice in Edinburgh in 1977, which he continues to run today.

Outgoing President, Professor Nairn Wilson said, 'I wish to be amongst the first to congratulate Hew Mathewson on his election... I very much hope that he finds his time as President to be as fulfilling as I have found my term of office.'

New GDC President, Hew Mathewson said, 'The new General Dental Council has a unique opportunity to redefine perceptions and challenge misconceptions while, at the same time, facilitating the delivery

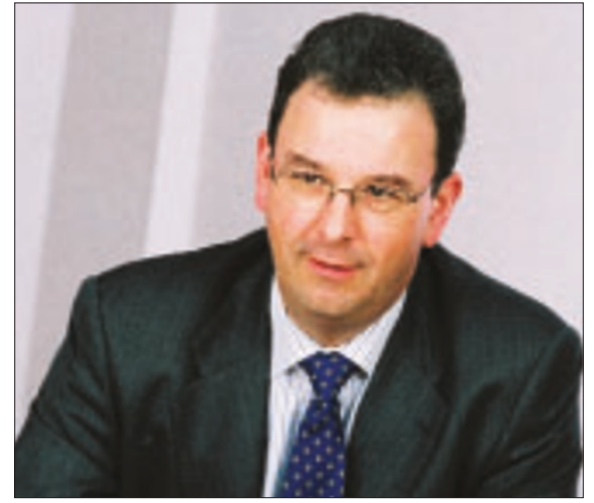

Hew Mathewson.

of an improving dental healthcare service to tens of millions of people. I am excited not only by the possibilities that lie ahead in terms of policy development but also by the challenge of creating sustainable partnerships across the dental profession.'

Hew has now taken office from the date of his election. 


\section{Software for scoring caries factors}

Cariogram is a software program which aims to demonstrate the multifactorial background of dental caries by illustrating the interaction of caries-related factors. Patients are scored on diet, plaque, caries experience and saliva secretion, and the results shown on a pie chart. Cariogram was devised by Professor Douglas Bratthall at the University of Malmo, initially as an educational program.

The program may be used, it is suggested, as being able to illustrate the chances of the patient developing caries in the coming year. The chart has five sections, which reflect diet, bacteria, susceptibility, circumstances and the likelihood of developing caries. However, although fairly strong associations have been found between caries experience and these factors, it does not mean that these factors can successfully predict future caries experience. In fact Professor Bratthall stresses that while Cariogram may act as a guide to caries risk, it never specifies the number of cavities which may occur. The software will also produce some suggested measures for the patient to implement in order to reduce or even eliminate their risk.

The susceptibility category takes into account how much fluoride the patient's teeth are exposed to as well as saliva secretion and saliva buffer activity. The circumstances category looks at a combination of past caries

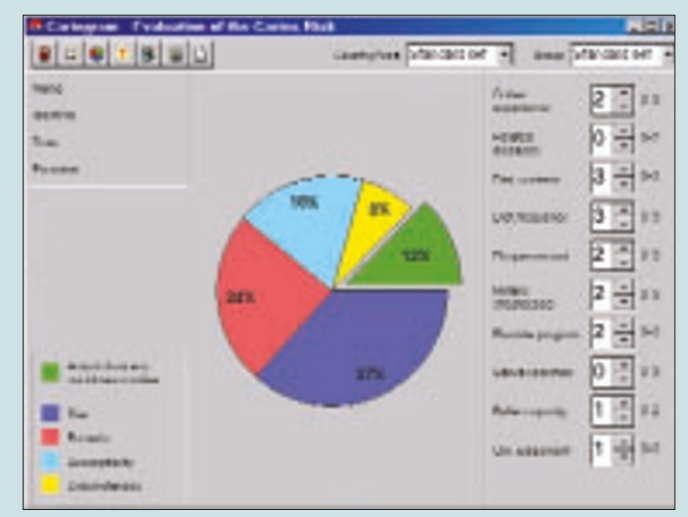

Cariogram chart showing high risk of caries

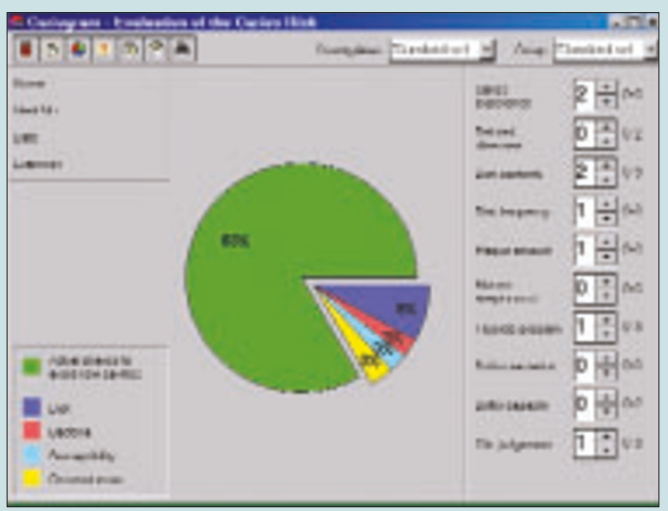

Cariogram chart showing low risk of caries experience and related diseases. These are balanced with diet and bacteria to produce the percentages.

Professor Bratthall believes that Cariogram's main principles will hold true in other countries although some of the factors which influence the scoring may vary. In these circumstances, practitioners are able to use their own clinical judgement to influence the outcome of the Cariogram. However, since the simulation model depends on salivary buffering and mutans tests which are not widely used in the UK, take-up of the software may not be so widespread as in Sweden. Its application is most likely to be in private practice on younger patients.

Professor Bratthall is program manager for the World Health Organisation oral database. He said his work on Cariogram began after he wrote to oral health experts around the world asking them to fill in a questionnaire on the factors which most influence caries reduction. Some thought it was better brushing, others thought it was better diet or use of fluoride. He decided he wanted to find a way of explaining all the different factors affecting caries and improved resistance to caries and how they relate to each other. Cariogram was produced in Sweden in 1997 and is now available in the UK through the British Dental Health Foundation. 


\section{Focus Awards expanded to encompass Northern Ireland and Wales}

The Focus Awards are set to expand to two new countries, with the nominations for 2003 opened up to include dental practices and clinics from Wales and Northern Ireland, as well as those from England.

After a successful pilot last year, patients will also be able to nominate their practices in all three countries.

There will be five categories this year, with each Focus Award winner receiving $£ 1,000$, and an overall winner receiving an additional $£ 1,000$. The categories for the 2003 Focus Awards are:-

- Excellence in children's dental care

- Excellence in treating those with special healthcare needs

- Excellence in patient information and involvement

- Excellence in creating a patient friendly environment

- Excellence in the development of good practice

Nomination forms for the Awards, which will this year be organised jointly by the BDA and the health departments of England, Wales and Northern Ireland, are now available from the BDA.

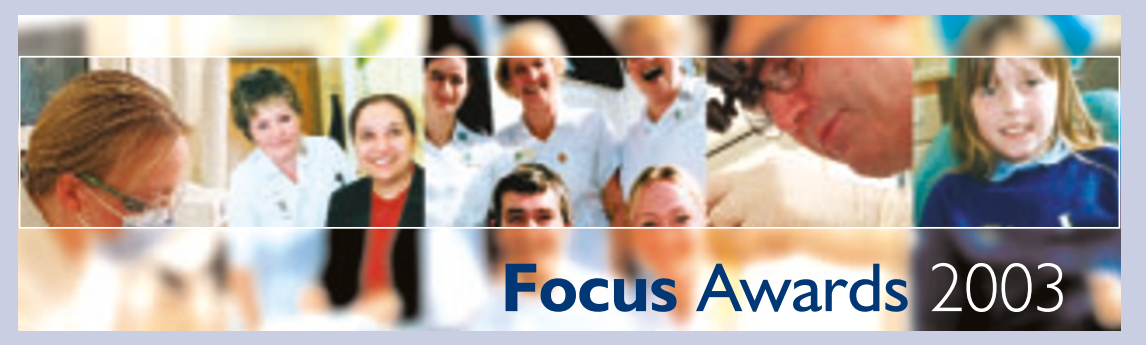

\section{Pay package meets mixed response}

The Department of Health's final threeyear pay offer for BDA members working in the NHS has met a mixed response from the General Dental Practitioners Committee and the Central Committee for Community Public Health Dentistry.

The main elements of the offer were -

- a $10 \%$ increase in pay and GDS fees over three years (3.225\% per year)

- a new mechanism for determining expenses to be negotiated

- a review of the salaried primary care dental service led by the Chief Dental Officer for England

- a capital fund of $£ 50 m$ in total, available over two years to both GDS practitioners and the salaried primary care dental service for modernisation and clinical quality.

GDPC members rejected this offer by 47 votes to 1 on the grounds that the deal fell well short of what was needed to keep the GDS afloat over the next two years. They asked that the negotiating team present evidence to the Review Body with a view to securing a one-year deal.

CCCPHD expressed serious concern about certain aspects of the offer but eventually accepted it by 25 votes to 3 . Their main reason for accepting the offer was that they could not afford to lose the promised review, an issue they had been cam-

\section{paigning for over many years}

These results were conveyed to the Department of Health on March 28th. The BDA is still awaiting their definitive response and that has caused serious delays in clarifying the issue for members.

The BDA's best understanding of the Department's position on salaried services is that they will agree to implement the three-year deal.

The DDRB (Doctors' and Dentists' Review Body) will now consider the written evidence already submitted by the BDA for a one-year deal for the GDS but, inevitably, the timetable for a recommendation will be much later than in previous years. Oral evidence will be heard in mid May and a report is anticipated in mid June. A new fee scale being would be introduced as soon as possible, perhaps from August 1st. The BDA has received the evidence to the DDRB from the Department of Health. This recommends that the increase in fees should be no more than the rate of inflation and 'be consistent with the awards already made in this round for the other review body groups i.e. between 2.25\% and 2.9\%'.

Evidence relating to the HDS will be submitted to the DDRB by the BMA. Updates will be available through the BDA website: www.bda-dentistry.org.uk 


\section{DIARY}

May 2003

Irish Dental Association Annual

Scientific Conference

Date: 07.05.03-10.05.03

Venue: Galway Radisson SAS Hotel,

Ireland

Contact: Joan Bracken

Tel: +35312830499

Fax: +35312830515

E-mail: joan@irishdentalassoc.ie

Older people with teeth

Date: 13.05 .03

Venue: King's Fund, London

Contact: Health links

Tel: +44 (0) 1212483399

Email:gbowling@health-

links.fsnet.co.uk

BDA/BDJ Clinical Seminars -

Removable Partial Dentures

Date: 17.05 .03

Venue: General Dental Council, London

Contact: Katherine Fort

Tel: +44 (0) 2075634166

Fax: +44 (0) 2075634591

Email:k.fort@bda-dentistry.org.uk

June 2003

SAAD 10th International Dental

Congress on Modern Pain Control

Date: 05.06.03-07.06.03

Venue: Edinburgh International

Conference Centre, Scotland

Contact: Congress Secretariat

Tel: +44 (0)141331 0123

Fax: +44 (0)1413310234

E-mail: info@saaduk.org

IADR 81st General Session

2nd Meeting of the Pan European

Federation

Date: 25.06.03-28.06.03

Venue: Svenska Mässan,

Gothenburg, Sweden

Contact: Michael Dominguez

Tel: + 17035480066

Fax: +1 7035481883

E-mail: Goteborg@laser-

registration.com

\section{September 2003}

Implementation of change in dental

education

Date: 08.08 .03

Venue: ASME, Edinburgh

Contact: ASME Secretariat

Tel: +44 (0)1312259111

Fax: +44 (0)1312259444

Email: info@asme.org.uk

\section{OFT reports on private dentistry market}

Better information on prices and treatments is required to improve competition and give consumers greater choice, an OFT study of the market for private dentistry has concluded.

This is the first study to have been initiated by a super-complaint, which in this case came from the Consumers' Association.

The UK market for private dentistry is expanding rapidly. It grew by just under 50 per cent in real terms between 1997 and 2001 and is currently valued at over $£ 1$ billion. Around seven million people regularly receive private dental treatment.

The full report, entitled The private dentistry market in the UK, can be ordered free of charge from the OFT or downloaded from their website at http://www.oft.gov.uk.

The OFT study finds that the market for private dentistry is not working well for consumers in some key respects. In summary:-

- consumers often lack basic information on prices, quality of services and what treatments are available on the NHS to enable them to make informed choices about private dentistry

- the standards promoted in professional guidance published by the General Dental Council (GDC), the statutory regulatory body for dentistry, are not routinely monitored and enforced and compliance in some areas is low

- unlike the NHS, there is no universal complaints system and procedures for dealing with complaints and securing redress for consumers are often inadequate

- regulatory restrictions on the supply of dentistry services, both for professionals complementary to dentistry (such as dental hygienists and therapists) and corporate dental bodies limit consumer choice, competition, business freedom and the potential to develop and deliver better services.
The OFT proposes that the current situation requires remedial action on three fronts. Firstly, there is a need to improve consumer information through better selfregulation. Secondly, the process of the resolution of problems must be tackled. Finally, the availability of dental services to consumers should be extended.

On improving consumer information, the OFT report recommends that self-regulation be strengthened. Compliance with the standards for patient information set out in the existing GDC guidance to dentists should be monitored and enforced. Professional standards should also be expanded to require that dental practices:

- clearly display guide prices on a range of common treatments

- display prominently details of what services are available under the NHS and what services the practice provides privately

- refer patients who want NHS treatment to a relevant body to help them find a new dentist who will treat them under the NHS if their current practice stops doing so.

The OFT has the following recommendations on the issue of complaints and patient problems and how to respond to them:-

- that each practice has a complaints procedure and that patients are made aware of this when they register with the practice

- that, in line with NHS procedures, an independent complaints procedure is established to examine complaints which cannot be resolved at practice level.

With regard to the supply of dentistry services, the OFT proposes that the restrictions on certain professionals complementary to dentistry (eg hygienists) should be ended, so that they are free to supply their services directly to consumers. It also supports the Department of Health (DH) proposals to remove the restriction on the number of corporate dental bodies under the Dentists Act, and furthermore, urges the DH to consider removing the remaining restrictions.

\section{BDA committee to be renamed}

The Central Committee for University Dental Teachers \&t Research Workers (CCUDTERW) is to be renamed as the Central Committee for Dental Academic Staff.

The new name will be adopted following the AGM at the BDA Conference in Manchester on the last weekend in April.

At the final meeting of the committee under its current name, the new Chair- man, Vice-Chairman and Executive Subcommittee were elected. The chairman is Dr John Drummond - Senior Lecturer and Honorary Consultant at the Dental School of University of Dundee. The Vice-Chairman is Dr David Hussey Senior Lecturer and Consultant in Restorative Dentistry at Queen's University, Belfast.

The newly elected committee members will stand for three years. 